$12-2016$

\title{
Mean hydroclimatic and hydrological conditions during two climatic modes in the Devils Lake Basin, North Dakota (USA)
}

Paul E. Todhunter

University of North Dakota, paul.todhunter@und.edu

How does access to this work benefit you? Let us know!

Follow this and additional works at: https://commons.und.edu/geo-fac

Part of the Geography Commons

\section{Recommended Citation}

Paul E. Todhunter. "Mean hydroclimatic and hydrological conditions during two climatic modes in the Devils Lake Basin, North Dakota (USA)" (2016). Geography \& Geographic Information Science Faculty Publications. 1.

https://commons.und.edu/geo-fac/1

This Article is brought to you for free and open access by the Department of Geography \& Geographic Information Science at UND Scholarly Commons. It has been accepted for inclusion in Geography \& Geographic Information Science Faculty Publications by an authorized administrator of UND Scholarly Commons. For more information, please contact und.commons@library.und.edu. 
Mean Hydroclimatic and Hydrological Conditions during Two Climatic Modes in the Devils Lake Basin, North Dakota (USA)

Paul E. Todhunter

Department of Geography

University of North Dakota

221 Centennial Drive Stop 9020

Grand Forks, North Dakota, USA, 58202-9020

Email: paul.todhunter@und.edu

Phone: (701) 777-4593

Fax: $\quad(701) 777-6195$ 
Abstract: Proxy variables from paleolimnological studies of lakes in the Prairie Pothole Region of North America have been used to infer large oscillations during the late Holocene between longer periods of high salinity-dry conditions, and shorter periods of low salinity-wet conditions producing a normative pattern marked by the absence of hydrological stability. Studies of the historical rise in lake level at Devils Lake have identified 1980 as a transition point between two such hydroclimatic modes. This study uses multiple datasets to characterize the mean hydroclimatological and hydrological conditions of these two climatic modes: mode 1 is a cool and dry phase, mode 2 is a warmer and wetter phase.

Precipitation onto the lake increased by $24 \%$ from mode 1 to mode 2 . This small but sustained increase produced significant changes in the mean hydroclimatic and hydrological states for the basin, including a $383 \%$ increase in surface runoff to the lake, and a $282 \%$ increase in the basin runoff ratio. Devils Lake Basin is located along a hydrotone or region of strong hydroclimatic gradients where small changes in hydrological drivers are amplified into large changes in regional moisture. The effects of the fluctuating climatic modes and strong hydroclimatic gradients are probably further amplified by the unique fill-spill hydrology of the northern glaciated plains, which can result in non-linear precipitation-runoff relationships. This natural pattern of extreme hydrological variations for Devils Lake produces enormous challenges for lake management. Key words: Devils Lake, terminal lake, hydroclimatic modes, water budget, runoff ratio 


\section{INTRODUCTION}

Approximately ten percent of the surface of Earth drains to inland lowland depressions (Waiser \& Robarts 2009). These inland terminal lakes are found on all continents ranging from cold to hot thermal regions, in hydroclimatic environments that vary between dry subhumid to arid conditions (Waiser \& Robarts 2009, Williams 2000). These terminal lakes are normally salty and, therefore, are often referred to as saline (salt) lakes. The number of terminal lakes and the total volume of water contained within them is not significantly less than open freshwater lakes (Williams 2000, 2002).

Terminal lakes are important hydrological systems that possess unique and dynamic physical, chemical, and biological properties. Because they lack an outlet for surface water outflow, terminal lakes can experience large and relatively rapid changes in water surface elevation, lake area, and lake volume due to short- and long-term climatic variations (Street 1980, Mason et al. 1994, Williams 1996). They are also sensitive to human modification of basin hydrology, and can experience significant lake level changes due to alteration of basin land use, land cover and river hydrology (Coe \& Foley 2001, Micklin 2007, Williams 2002). Terminal lakes face significant threats from anthropogenic climate change, human abstractions of freshwater, and land cover change in their contributing basins (Williams 1996, 2002). These properties call for careful management to ensure their ecological health and contribution to societal sustainability (Williams 1998, ILEC 2005). 
Devils Lake is a permanent terminal lake located in the Devils Lake closed drainage sub-basin in eastern North Dakota (Fig. 1). The closed basin has an area of $9,868 \mathrm{~km}^{2}$, of which $8,599 \mathrm{~km}^{2}$ drains to Devils Lake and $1,269 \mathrm{~km}^{2}$ to an adjacent terminal lake to the east called Stump Lake. Devils Lake began spilling into Stump Lake in 1999, and the two lakes now form a single lake system. At an ordinary high water mark of 444.40 m Devils Lake spills into the Sheyenne River, and becomes part of the Red River of the North drainage basin draining into Canada.

Devils Lake has a number of distinctive features that make it unique among the world's terminal lakes. First, the lake formed due to glacial ice thrusting during the last glaciation (Bluemle \& Clayton 1984). Second, the lake region has a mean annual air temperature of $3.8^{\circ} \mathrm{C}$, a mean annual precipitation of $44.9 \mathrm{~cm}$, and a mean annual net evaporation of $24.1 \mathrm{~cm}$, placing the lake just below the climatic limit for open lakes (Williams 1998, 2002). In spite of its dry subhumid environment, geological field investigations summarized by Bluemle et al. (1999) show extreme lake level fluctuations over the geological record, and suggest that Devils Lake has gone completely dry perhaps five times, and spilled over to the Red River of the North perhaps three times over the past 4,000 years. Third, the fluctuating lake levels over The Holocene led to the formation of very productive agricultural soils; the upper Devils Lake Basin is among the most intensively farmed rainfed agricultural regions in the United States. Finally, the lake has experienced catastrophic flooding over the past two decades (Larson 2012). From 
30 September 1992 to 30 September 2013 the lake level (LL) rose from 433.62 to $442.75 \mathrm{~m}(\Delta=9.13 \mathrm{~m})$, lake area $\left(L_{A}\right)$ expanded from 179.9 to $694.6 \mathrm{~km}^{2}(\Delta=$ $286 \%$ ), and lake volume (Lv) increased from 0.704 to $4.003 \mathrm{~km}^{3}(\Delta=469 \%)$ (Fig. 2). Direct federal and state payments for flood damages have exceeded \$1 Billion (\$USD) (Leistriz et al. 2002, Zheng et al. 2014), although direct flood damages are a conservative estimate of total flood losses (Smith \& Katz 2013). The lake provides an excellent example of a chronic climate hazard that lies outside the scope of traditional hazard mitigation principles (Riebsame 1985, Guppy \& Twigg 2013).

Proper management of the lakeshore environment below the ordinary high water mark requires an accurate assessment of lake levels over long time scales that extend beyond the systematic observational record. Combining systematic data from hydrological networks, historical data from documentary sources, and proxy records from paleolimnological investigations can provide a more accurate understanding of the long-term range of climatological conditions and hydrological responses in the terminal lake basin (Knox 2000, Benito et al. 2004). Natural climate variability leads to dynamic changes in flood characteristics and probability. A more quantitative understanding of the time-varying flood risk with fluctuations in regional climate provides an improved foundation for flood risk managers (Merz et al. 2014).

Proxy variables from multiple paleolimnological investigations have been used to examine Holocene climate variability in northern Great Plains saline lakes 
(Haskell et al. 1996, Laird et al. 2003, Shapley et al. 2005, Grimm et al. 2011). These studies capture decadal-scale climate variability and reveal a regionally coherent pattern during the late Holocene of large oscillations between longer periods of high salinity-dry conditions, and shorter periods of low salinity-wet conditions. The transitions between high salinity/low salinity modes appear to be relatively rapid, suggesting large and abrupt transitions in the climatic drivers controlling moisture availability (Haskell et al. 2000, Laird et al. 2003). The paleohydrology of the Devils Lake region over the past 12,000 years shows the absence of even short-term hydrological stability. The Late-Holocene record of climatic variability provides a critical background upon which to evaluate historical observations of lake level fluctuations, and changes in the hydrological response of the basin. It documents the range of natural climatic variability present in a hydrological system before the complicating effects of anthropogenic climate change and human land use changes are superimposed (Knox 2000).

Studies of the climatological basis of the historical rise in lake level at Devils Lake have identified 1980 as a transition point between two such hydroclimatic modes (Vecchia 2008, Hoerling et al. 2010, Todhunter \& Fietzek-DeVries 2016). The contrasting methods and independent datasets used in the three studies affirm 1980 as the year of abrupt change between different and contrasting hydroclimatological regimes.

Kunkel et al. (1994) and Bell and Janowiak (1995) examined the atmospheric circulation features associated with the dramatic rise in Devils Lake 
that began abruptly in 1993. A more general understanding of the longer-term atmospheric circulation drivers of precipitation, streamflow, and lake level fluctuations in the northern Great Plains over decadal- to millennial-scale periods has remained elusive (McCabe et al. 2004, Woodhouse et al. 2009, McCabe \& Wolock 2014, Grimm et al. 2011, Kluver \& Leathers 2015). Research on hydroclimatic variability in the United States has focused on quasiperiodic variations in sea surface temperature in the tropical Pacific Ocean, eastern Pacific Ocean, and North Atlantic Ocean (McCabe et al. 2004, McCabe \& Wolock 2014). No single climatic index has emerged as a dominant driver for the region, however, and two or more indices may be in phase or out of phase with one another, at times weakening or reinforcing each index (Woodhouse et al. 2009).

The purpose of this study is to characterize the mean hydroclimatological and hydrological conditions of the two circulation modes that are evident in the paleolimnological record of the past 4,000 years, and have also been documented in the historical record during the $20^{\text {th }}$ Century. A diverse set of climatological, hydrological, water balance, and closed lake variables will be used to characterize the two modes. These results will help to explain the dramatic lake level changes over this period (Fig. 2), and have important implications for effective long-term management of the lake resource.

\section{BACKGROUND}

\subsection{Study Area}


The basin lies within the Northern Glaciated Plains ecoregion that has experienced moderate land cover change between 1973 and 2000 (Drummond et al. 2012). The Drift Prairie landscape lies within the Glaciated Plains physiographic region, and was traversed by a continental ice sheet during the last glaciation (Bluemle \& Clayton 1984). The Devils Lake system consists of a series of separated bays formed from the thrusting of subglacial materials as the advancing ice sheet moved over the saturated Spiritwood Aquifer (Bluemle \& Clayton 1984). Total relief between the bottom of Devils Lake Basin and the hills to the south of the lake complex in this ice-thrust topography is just over 200 meters (Bluemle \& Clayton 1984).

The upper basin is divided into a series of sub-basins, with each sub-basin drained by a single major coulee that flows south and empties into one or more lakes (Ryan \& Wiche 1988) (Fig. 1). The lakes form a chain of lakes, each of which is located within a glacial depression, and separated from one another by a swale with a unique spill elevation. Runoff along the chain of lakes, when it occurs, proceeds in an east to west direction, and enters into northwest Devils Lake through Big Coulee.

The continental ice sheet also left numerous topographically-closed depressions, called prairie potholes, of variable size and depth (Shaw et al. 2013). The Drift Prairie consists of clay-rich surficial deposits underlain by Cretaceous shale; both possess very low hydraulic conductivity and low permeability that, in combination with the limited relief, results in very small groundwater flow rates. 
Water storage in the prairie potholes is normally highest in the spring following the melt of the winter snow accumulation on the frozen water surface, and the runoff of snowmelt from the adjacent prairie landscape, the latter water source being enhanced by the limited infiltration rates due to the seasonally frozen soils (van der Kamp \& Hayashi 2009).

\subsection{Basin Hydrology}

Hydrologic response in the basin is controlled by principles of fill-spill hydrology that operate at two spatial scales and is a product of the basin's glacial history. At the basin scale, runoff within a sub-basin drains to its lake in the chain of lakes, but does not contribute directly to the next lower lake in the chain until the swale elevation separating the two sub-basins is reached and the upper lake can spill into the lower lake in the chain. Only when all of the lakes are at spill elevation and flowing over their respective swales to the next lower-lying sub-basin does the full upper basin area contribute runoff into Devils Lake. If any lake along the chain is below spill elevation its sub-basin area and that of all sub-basins further up the chain does not contribute runoff into Devils Lake (Ryan \& Wiche 1988).

At the sub-basin scale, a significant portion of the area drains internally to wetland complexes that frequently do not fill to a high enough level to drain to downstream areas; thus surface water drainage between adjacent wetland depressions is normally disconnected. Much of the upper Devils Lake Basin lacks a well-defined surface drainage system, and much of the area is non-contributing 
to streamflow in most years. Surface inflow to Devils Lake $\left(R_{i}\right)$ is strongly dependent upon basin antecedent moisture conditions, water storage in wetland depressions, connectivity between adjacent wetlands, and the variable area contributing surface flow to Devils Lake (Shook \& Pomeroy 2011, Ehsanzadeh et al. 2012, Shaw et al. 2012, 2013, Dumanski et al. 2015).

\subsection{Historical Lake Levels}

Three phases of historical lake rise are indicated in Figure 2. Phase I ended in spring 1999 when Devils Lake Lı reached $440.89 \mathrm{~m}$ and began to spill into Stump Lake. Phase II ended in summer 2007 when Devils Lake and Stump Lake reached the same $L\llcorner$ of $440.89 \mathrm{~m}$. At this time the two adjacent lakes became a single lake system, and the $1,269 \mathrm{~km}^{2}$ Stump Lake drainage area was added to the $8,599 \mathrm{~km}^{2}$ Devils Lake drainage area for a combined lake system drainage area of $9,868 \mathrm{~km}^{2}$. Devils Lake is currently in phase III that will continue until either the combined lake system reaches the ordinary high water mark of $444.40 \mathrm{~m}$ and spills to the Sheyenne River, or it drops below $440.89 \mathrm{~m}$ and splits back into two separate lakes.

\section{DATA AND METHODS}

\subsection{Lake Water Budget}

The differential equation for the water balance of a terminal lake states that the rate of change in lake volume (Lv) with time $t$ is:

$$
\frac{d L_{V}}{d t}=R_{i}+P_{L} L_{A}+G_{i}-E_{L} L_{A}-G_{0}
$$


where $R_{i}$ is surface runoff into the lake $\left(\mathrm{km}^{3}\right), P_{L}$ is direct precipitation onto the lake $(\mathrm{mm}), L_{A}$ is lake area $\left(\mathrm{km}^{2}\right), E_{L}$ is evaporation from the lake $(\mathrm{mm})$, and $G_{i}$ and $G_{0}$ are groundwater flow into and out of the lake (Mason et al. 1994). Wiche and Pusc (1994) estimate that shallow ground water inflow from glacial till deposits surrounding the lake and deep ground water contributions to the lake are only $0.0037 \mathrm{~km}^{3} \mathrm{yr}^{-1}$, and thus are not a significant factor in explaining annual lake fluctuations. Ground water outflow is similarly negligible.

In the summer 2005 construction began on a series of outlets to pump water from the Devils Lake system to reduce flood damages (North Dakota State Water Commission 2014). While operative, the two outlets have a pumping capacity of $17.0 \mathrm{cms}$. The last year of insignificant pumping volume was 2010 which, therefore, will mark the ending date of the analysis (W. Schuh, personal communication, 22 June 2015).

\subsection{Monthly Lake Water Budget Data}

Monthly water budget data for Devils Lake were obtained from the USGS North Dakota Water Science Center (A. Vecchia, personal communication, 14 October 2011). These included monthly totals of lake precipitation $(P L, m m)$, lake evaporation $(E L, m m)$ and inflow $\left(R \mathrm{i}, \mathrm{km}^{3}\right)$ for January 1950 through December 2010. Net lake evaporation ( $E\llcorner-P\llcorner, \mathrm{~mm}$ ) was determined as a secondary variable from the primary data. Full details concerning the estimation of the monthly $P_{L}, E_{L}$, and $R_{i}$ time series are given in Wiche and Vecchia (1996) and Vecchia (2002, 2008). The monthly water budget model was constrained by monthly 
measurements of lake volume $\left(\mathrm{Lv}, \mathrm{km}^{3}\right)$; monthly estimates of the water balance variables were calculated from selected observed climate and hydrological data using multiple regression techniques that minimized variance and produced unbiased estimates. These primary data were previously used to conduct the lake level frequency analysis for Devils Lake (Wiche \& Vecchia 1996), and two versions of a stochastic simulation model used to evaluate the impact of pumping from proposed outlets upon future lake levels (Vecchia 2002, 2008). The total inflow term $\left(\mathrm{R}_{\mathrm{i}}\right)$ includes the sum of gaged inflow from relevant USGS stream gages, and local ungaged inflow from the adjacent lake periphery.

\subsection{Historical Lake Levels and Lake Hypsometry}

Historical observations of lake level for Devils Lake were obtained from USGS Water Data for the Nation (USGS 2013). Figure 2 is a composite of infrequent $19^{\text {th }}$ Century survey elevations, annual observations through 1930 , monthly measurements from 1931-1965, and daily observations from the 1965 to the present. The complete lake hypsometry defining the relationships between lake level, lake area, and lake volume are normally not known for closed lakes, but is available for Devils Lake. Tables of $L_{L}-L_{A}$ and $L_{L}-L_{v}$ relationships for lake levels between 426.7-445.6 $\mathrm{m}$ (1400.0-1462.0 feet) were available from the USGS (2014), which allowed the creation of a Lv time series from the historical LL series.

\subsection{PRISM Data}

Monthly precipitation and mean monthly maximum and minimum air temperature were obtained from the PRISM web page for the period 1895-2011 
(www.prism.oregonstate.edu) by interpolating values from the PRISM database using the coordinates of the USGS gaging station on Devils Lake (Figure 1). Annual water year precipitation $\left(\mathrm{PwY}_{\mathrm{w}}, \mathrm{mm}\right)$ and mean annual water year air temperature $\left(\mathrm{T}_{\mathrm{WY}},{ }^{\circ} \mathrm{C}\right)$ totals were created from the monthly totals. PRISM data has been validated by Daly et al. (2008), and has been used in numerous hydroclimatological investigations (Sankarasubramanian \& Vogel 2003, Small et al. 2006, Todhunter \& Fietzek-DeVries 2016).

\subsection{Water Balance Model}

This study uses the monthly water balance model implementation of McCabe and Markstrom (2007) driven by the monthly temperature and precipitation data described in Section 3.4. An overview of the water balance model is presented in Todhunter and Fietzek-DeVries (2016), while more detailed descriptions and model validations tests are available in Wolock and McCabe (1999), Hay and McCabe (2002), and McCabe and Markstrom (2007). Hay and McCabe (2002) found that model results varied little across a wide range of model input parameter values, so default values were used in the model run. Selected climatic and soil moisture-based model output variables are used to characterize long-term basin hydroclimatic conditions.

\section{RESULTS}

\subsection{Hydroclimatic Modes}

The method of Hurst rescaling was used to identify regime transitions and periods of relative homogeneity within the geophysical time series. The method is 
presented in Outcalt et al. (1997), and illustrated in Todhunter and Fietzek-DeVries (2016). A normalized transformed time series can be obtained from individual geophysical time series in which each normalized transformed time series ranges from 0 to 1.0 . Use of the normalized transformed time series is particularly advantageous since it allows a direct comparison of separate geophysical time series having different metrics, starting and ending dates, and periods of record (Outcalt et al. 1997).

Each normalized transformed time series can be plotted and visually inspected for regime transitions. An ascending (descending) trace indicates a period of above average (below average) time series values, where the steepness of the slope is related to the rate of deviations from the mean. Inflection points in the plotted time series indicate regime transitions from periods of positive to negative cumulative deviations from the mean (or vice versa). The graphical plots of the normalized transformed times series are much easier to interpret than the original time series, and present a more consistent means of decomposing a time series into more homogeneous subsets.

Normalized transformed time series plots of annual water year precipitation (Pwy), mean annual water year air temperature (TwY), and lake volume (Lv) on 30 September for the period 1901-2011 are shown in Figure 3. The vertical dashed line marks a regime transition in 1980 that separates hydroclimatic mode 1 from hydroclimatic mode 2 (Todhunter \& Fietzek-DeVries 2016). The Pwy trace shows the long-term variation in the basin atmospheric supply of moisture, while the TwY 
trace shows the long-term variation in atmospheric demand across the basin. The Lv trace shows how the lake water budget varies in response to these two basic hydrologic drivers.

The normalized transformed plot of $\mathrm{P}_{w y}$ has an inflection between positive and negative deviations from the long-term mean in 1906, followed by a general accumulation of negative deviations lasting through 1980. Pwy values then begin a rapid accumulation of positive deviations to the end of the time series. The plot of the normalized Twy series shows a continuous accumulation of negative deviations through 1920, a period of relatively stable deviations through 1980 , followed by a period of continuous and rapid accumulation of positive deviations through the end of the period of record. The normalized Lv plot shows a continuous accumulation of negative deviations below the long-term mean from 1901 until reaching a minimum in 1980. Although lake level reached a minimum near 1940 (Fig. 2), the cumulative deviations of lake level below the long-term mean continued to be negative through 1980. In 1993, the normalized Lv series began an abrupt and rapid positive accumulation of deviations from the long-term mean value, reaching a maximum value in 2011.

The rescaled Pwy and Twy series reveal two distinct hydroclimatic periods during the historical period. Hydroclimatic mode 1 is a cool and dry phase that lasts from the beginning of the period of record through 1980, while hydroclimatic mode 2 is a warmer and wetter phase that begins in 1981 and continues through the end of the period of record. 


\subsection{Lake Hydrology Variables}

The two hydroclimatic modes are associated with significantly different hydrological and hydroclimatic conditions. Annual totals for the individual lake water budget variables are show in Figure 4 for water years 1951-2010. The use of a water year allows winter snow accumulation, spring snowmelt production, and summer thunderstorm precipitation to be included within the same year.

Annual precipitation onto the lake surface $(P L)$ averages $522.7 \mathrm{~mm}$, ranges between 248.0 to $795.5 \mathrm{~mm}$, and has a coefficient of variation (CV) of $21.1 \%$ (Table 1). Precipitation is concentrated in the summer months, which is characteristic of mid-latitude prairie climates (Barry \& Hall-McKim 2014); mean monthly precipitation ranges from a low of $15.2 \mathrm{~mm}$ in February to a high of 95.2 $\mathrm{mm}$ in June.

Annual lake evaporation ( $\mathrm{E}_{\mathrm{L}}$ ) averages $763.4 \mathrm{~mm}$, but only ranges between 652.5 to $966.5 \mathrm{~mm}$, with a CV of $8.3 \%$ (Table 1). The lake freezes over in winter so that significant lake evaporation only occurs between April-November. On 30 September 2010 the maximum lake depth was about $15.0 \mathrm{~m}$, and the average lake depth was about $5.8 \mathrm{~m}$. The shallow lake depth, large wind fetch, and active regional wind regime results in a well-mixed lake with a single thermal layer and minimal lake heat storage, so that the maximum average lake evaporation of $152.7 \mathrm{~mm}$ lags only until August.

Lake net evaporation $\left(E_{L}-P_{L}\right)$ determines how rapidly lake level can be naturally drawn down since it is the only means of water loss in the absence of 
human abstractions or surface discharge should the lake level exceed the ordinary high water mark. Average lake net evaporation is $240.8 \mathrm{~mm}$ (Table 1), with annual totals ranging from $-73.4 \mathrm{~mm}$ to $586.7 \mathrm{~mm}$, with $\mathrm{P}_{L}$ exceeding $\mathrm{E}_{\mathrm{L}}$ in three of the sixty years of record. The CV for lake net evaporation is $58.9 \%$, which is the second highest $\mathrm{CV}$ of the four lake water budget variables (Table 1).

Surface inflow to the lake $\left(R_{i}\right)$ is the most variable lake water budget term. Mean annual surface water inflow is $0.120 \mathrm{~km}^{3}$ (Table 1), but this total ranges between 0.0 to $0.720 \mathrm{~km}^{3}$, producing a CV of $141.3 \%$. Surface inflow to the lake is dominated by snowmelt production, with peak $R_{i}$ totals normally occurring in April. Winter precipitation (Dec-Feb) is $9.3 \%$ of annual precipitation, but spring surface inflow (Mar-May) is $69.0 \%$ of annual surface inflow to the lake. Summer runoff (Jun-Aug) to the lake is only $23.6 \%$ of annual $R_{i}$ even though summer precipitation is $45.9 \%$ of annual PL.

Table 2 shows the difference in the average values of the four lake water budget variables between the two hydroclimate modes. The lake water budget variables show profound changes between the warmer and wetter mode 2 and the cooler and drier mode 1. Mode $2 \mathrm{P} L$ averages $112.8 \mathrm{~mm}$ more than for mode 1 , for an average increase of $24 \%$. Although mode 2 is significantly warmer than mode 1 (Table 2), EL averages only $22.1 \mathrm{~mm}$ more than for mode 1 for a minor increase of $3 \%$. Lake net evaporation $(E L-P L)$, however, is significantly affected, experiencing a $32 \%$ decrease. The effects of these relatively modest annual changes in $P L, E L$ and $E_{L}-P L$ upon the surface hydrology, however, are greatly 
amplified when sustained over a long period of time. Average surface inflow to the lake is $0.157 \mathrm{~km}^{3}$ greater for model 2 than for mode 1 , corresponding to an increase of $383 \%$.

\subsection{Closed Lake Variables}

Two of the variables in Table 2 have been used in the literature to compare closed lakes because such systems occur along a wide range of hydroclimatic conditions (Szesztay 1974, Mason et al 1994). The first is the inflow factor (I, \%):

$$
I=\frac{R_{i}}{R_{i}+P} \times 100
$$

where $R_{i}=$ surface inflow to the lake $\left(\mathrm{km}^{3}\right)$, and $P=$ direct precipitation onto the lake surface $\left(\mathrm{km}^{3}\right)$, where $P$ is the product of the annual water year total of $P$, and LA obtained on 30 September. Also included is the climate parameter:

$$
C=\frac{P_{B} \cdot r}{E_{L}-P_{L}}
$$

where $0.0 \leq C \leq 1.0$ and is an inverse measure of aridity (Szesztay 1974), with $C=$ 1.0 marking the transition from terminal lakes to open lakes. Here $P_{B}=$ average precipitation onto the basin $(\mathrm{mm}), \mathrm{E}_{\mathrm{L}}=$ lake evaporation $(\mathrm{mm})$, and $\mathrm{r}=$ runoff coefficient, such that

$$
r=\frac{R_{i}}{B_{A} \cdot P_{B}}
$$

This assumes that $P_{B}=P_{L}, B_{A}=$ basin area $\left(\mathrm{km}^{2}\right)$, and that

$$
A=L_{A}+B_{A}
$$


where $A=$ closed basin area $\left(\mathrm{km}^{2}\right)$, and $L_{A}=$ lake area $\left(\mathrm{km}^{2}\right)$. Direct precipitation onto the lake surface $\left(\mathrm{P}, \mathrm{km}^{3}\right)$ is the primary input to Devils Lake during both hydroclimate modes, with I averaging $23.9 \%$ in mode 1 and $36.5 \%$ in mode 2 . The relative contribution of $R_{i}$ to total lake input, however, is $53 \%$ greater for mode 2 than for mode 1 . The basin climate parameter is also noticeably less arid during mode 2 than mode 1.

\subsection{Water Balance Variables}

The seven water balance variables in Table 2 show how the amount and annual variability of soil moisture storage controls the partitioning of precipitation into evapotranspiration and runoff (Hay \& McCabe 2002). They serve as indicators of regional moisture conditions, are directly related to important water resource variables such as runoff and groundwater recharge, and are effective at integrating the multiple drivers of regional hydroclimatic variability. They include the FAO aridity index (Pwy/PET, fraction) (Spinoni et al. 2015), mean annual water year air temperature $\left(\operatorname{Tw}_{w y},{ }^{\circ} \mathrm{C}\right)$, mean annual precipitation minus mean annual potential evapotranspiration (PMPE, mm), annual water deficit (PET-AET, mm), mean monthly soil moisture storage (SM, mm), the dryness index (PET/PwY, fraction), and the annual moisture index (IM100, -100 $\leq \mathrm{IM} 100 \leq 100)$ (Willmott \& Feddema 1992, Grundstein 2009).

Mode 2 is significantly wetter and warmer than mode 1, with PwY averaging $112.8 \mathrm{~mm}$ more precipitation and Twr averaging $0.63^{\circ} \mathrm{C}$ warmer than for mode 1 (Table 2). The effect of increased surface moisture input upon the regional 
moisture status exceeds the effect of increased atmospheric demand of surface moisture as shown by the remaining water balance variables. Multiple indices reveal the lower aridity of mode 2 compared to mode 1 : the excess of annual potential evapotranspiration over annual precipitation (PMPE) is $75.8 \mathrm{~mm}$ lower; the amount by which annual potential evapotranspiration exceeds annual actual evapotranspiration (PET-AET) is $59.5 \mathrm{~mm}$ less; average monthly soil moisture content (SM) is $40.1 \mathrm{~mm}$ higher; and the annual dryness index decreased from 1.36 to 1.16 , and the annual moisture index increased from -23.6 to -10.0 . Both summary indices indicate a less arid regime that is closer to the boundary separating dry and moist hydroclimate regimes (i.e., PET/PWY $=1.0$, and IM100 = $0.0)$.

\subsection{Precipitation-Runoff Variable}

A final variable in Table 2 is the runoff ratio $(\mathrm{RR}, \%)$. It is defined as:

$$
R R=\frac{R_{i}}{P_{B} \cdot B_{A}} \times 100
$$

It represents the volume of runoff to the lake $\left(\mathrm{R}_{\mathrm{i}}\right)$ divided by the volume of water falling on the sub-basin and is expressed as a percentage. The time series of $R R$ for the 60 -year period is shown in Figure $5 ; 0.0 \leq R R \leq 14.3 \%$, and only one year had no runoff $\left(\mathrm{R}_{\mathrm{i}}\right)$, although many years experienced minimal runoff with $\mathrm{RR}$ values close to zero. The average $R R$ value is $2.6 \%$, but the interannual and longterm variation is extreme, with a coefficient of variation of $136 \%$, and with $R R$ fluctuating by more than two orders of magnitude. RR averages $1.08 \%$ for mode 
1 , and $4.12 \%$ for mode 2 , for a $282 \%$ increase (Table 2 ). The large interannual and long-term variation in $\mathrm{R}_{\mathrm{i}}$ is also reflected in the range of the inflow factor for the lake $(\mathrm{I}, \%)$. Surface runoff to the lake contributes between 0.0 to $75.0 \%$ of total water input to the lake; the average value of $\mathrm{I}$ is $30.2 \%$, but ranges by more than two orders of magnitude over the period of record.

\section{DISCUSSION}

Bluemle et al. (1999) state that the natural condition for Devils Lake is to be rising toward overflow to the neighboring Stump Lake or Sheyenne River, or falling toward desiccation as a dry lake bed. Paleoclimate research over the past two thousand years reveals large oscillations between wet and dry phases in the northern Great Plains (Shapley et al. 2005), during which long periods of stable lake levels are uncommon. The low frequency changes in lake levels must be linked to atmospheric circulation anomalies affecting the penetration of humid air masses, and the location of seasonal storm tracks (Hirschboeck 1987, Knox 2000), which cause long-term variations in precipitation and air temperature that, along with appropriate thresholds, time lags, and lake bathymetry effects, drive long-term variations in lake level (Mohammed \& Tarboton 2011). Efforts to link these multi-decadal to century-scale moisture variations to specific atmospheric

circulation indices, however, have remained elusive for this region (Grimm et al. 2011).

Researchers have identified 1980 as one such transition between a cool and dry mode, and a warm and wet mode (Vecchia 2008, Todhunter \& Fietzek- 
DeVries 2016). This produced what has been called a 'drought to deluge cycle' marked by tremendous regional changes in hydrological states, including precipitation amount, the number, depth, and permanence of prairie pothole wetlands (Todhunter \& Rundquist 2004, Winter \& Rosenberry 1998, Zhang et al. 2009), groundwater table depths, vadose zone storage, streamflow volumes, and lake levels (Fig. 3).

Small but sustained changes in atmospheric circulation patterns in the northern Great Plains can produce abrupt, persistent and significant changes in hydrological response of river basins (Hirschboeck 1987, Knox 2000). The multiple hydroclimatic, closed lake, and hydrologic variables presented in Table 2 reveal distinct differences in the climatic states and hydrologic conditions of the two modes. Mode 1 extends back to 1907 (Fig. 3), and probably back to at least the mid-1800s based upon the limited historical observations recorded prior to the systematic record (Fig. 2). Mode 1 was cooler, drier, more arid, and characterized by much reduced levels of hydrological states such as surface runoff. Mode 2 is warmer, wetter, less arid, and supports a significantly more active runoff regime.

Precipitation onto the lake $(P\llcorner)$ increased from $466 \mathrm{~mm}$ to $579 \mathrm{~mm}$ from mode 1 to mode 2 . This $24 \%$ increase shifts Devils Lake from the semiarid (250$500 \mathrm{~mm})$ to the subhumid $(500-750 \mathrm{~mm})$ class within the dryland classification of Williams (2000). Both modes remained within the dry subhumid moisture class in the Thornthwaite classification (-33 $\leq \mathrm{IM} 100 \leq 0)$ (Grundstein 2009), but the change in IM100 from -23.6 for mode 1 to -10.0 for mode 2 shifted the station from 
the more arid to the less arid limit of that class. Mohammed and Tarboton (2011) show that the frequency distribution of lake levels in terminal lakes can display preferred states due to the multimodality of hydrological forcing which are then translated into a lake level frequency distribution by lake bathymetry. The histogram of historical lake volumes shown in Todhunter and Fietzek-DeVries (2016) further illustrates these hydroclimatic modes.

The Devils Lake Basin is located along a strong longitudinal climatic gradient that characterizes the United States Great Plains region (Rosenberg 1986). Most climatic gradients trend west-east reflecting the controlling effect of latitude, but in the United States Great Plains climatic gradients trend north-south, due to the decreasing westward trend of available moisture. The basin lies along the dry subhumid/moist subhumid boundary in the Thornthwaite classification system (Feddema 2005, Grundstein 2009). The boundary marks a 'hydrotone,' or a large and systematic change in hydroclimatic conditions across a relatively short geographical distance, and experiences large spatial variations in moisture availability and water demand across the region (McCabe \& Wolock 2002). In general, the mean state of moisture variables decreases and the interannual variability of the standard deviation and coefficient of variation of the variables increases trending from east to west (McCabe \& Wolock 2002). Mean measured and modeled runoff depth decrease sharply across the gradient (Wolock \& McCabe 1999, McCabe \& Wolock 2011), as does the mean basin runoff ratio (Chang et al. 2014). 
The longitudinal boundary separating the moist subhumid $(\mathrm{IM} 100>0)$ from the dry subhumid $(\mathrm{IM} 100<0)$ regions represents a mean position averaged over a number of years (Feddema 2005), and reflects the average position of storm tracks and air mass trajectories. On an interannual basis the boundary shifts east during dry years and west during wet years. Similarly, its mean position shifts in response to changes in the circulation anomalies that characterize the two hydroclimate modes, shifting eastward during drought periods, and westward during deluge periods. The relatively moderate shifts in the longitudinal position of the IM100 = 0 boundary during modes 1 and 2, combined with the sharp hydroclimatic gradients present along the hydrotone may be sufficient to produce the relatively large differences in the hydroclimatic, hydrologic, and water balance variables obtained (Table 2).

Risbey and Entekhabi (1996) showed that precipitation variability was most strongly related to precipitation variability, with only minor, if any, variability explained by temperature (or potential evapotranspiration) effects. The strong temporal coherence of the Pwy and Lv traces in Figure 3, and the more inconsistent fit of the Twy trace with Lv shows that long-term, low-frequency variations in precipitation are the dominant driver of lake volume changes for Devils Lake. Ryberg et al. (2014) report similar conclusions for the north central region, while McCabe and Wolock (2011) found the same pattern for the coterminous United States. The small 24\% increase in $\mathrm{PL}$ from mode 1 to mode 2 (Table 2), when sustained over long periods of time, leads to greatly increased 
surface runoff volume (Fig. 4). When the transition to a wetter circulation mode occurs after a prolonged drought episode, a significant lag may be anticipated before lake volume responds positively, as shown in Figure 3 (Ryberg et al. 2014).

The $282 \%$ increase in the runoff ratio $(\mathrm{RR})$ from mode 1 to mode 2 also suggests, however, a highly non-linear relationship between basin precipitation (Pwy) and basin runoff $\left(\mathrm{R}_{\mathrm{i}}\right)$. Such a relationship has been demonstrated for watersheds within the glacial drift prairie region of Canada (Dumanski et al. 2015, Ehsanzadeh et al. 2012, Shaw et al. 2012, 2013, Shook \& Pomeroy 2011, Shook et al. 2015), and has been shown to similarly hold true for the Devils Lake Basin. The prairie pothole region of North America follows principles of fill-spill hydrology, where the innumerable wetland complex depressions experience variable water storage and intermittent hydrological connectivity with adjacent wetland complexes and downstream river networks. This results in dynamic and variable contributing areas during both the annual hydrological cycle and between prolonged wet and dry spells.

The historical management of Devils Lake has always proceeded on an ad hoc basis, reflecting what Morrisette (1988) called 'the stability bias.' This approach focuses on short-term adjustments to lake level variability to maximize immediate economic benefits, while ignoring strategies that would promote sustainable, long-term regional development. The paleolimnological record shows that the lake level has never been stable over the late Holocene, but has fluctuated between two distinct hydroclimatic modes. Even lake level 
measurements since first European contact reveal a deluge to drought to deluge pattern that nearly encompasses the full range of lake level variability within the lifetime of selected older residents in the region (Fig. 2). The natural variability of the lake presents tremendous challenges for agricultural production, recreational fisheries, recreational development of the lakeshore environment, flood mitigation, and transboundary water resource issues. A final management challenge concerns the possible effects of anthropogenic climate change, and whether the natural record of lake level variability contained in the paleolimnological record will continue, or will the timing, duration, and even existence of the two hydroclimatic modes be altered.

\section{ACKNOWLEDGEMENTS}

I thank Rick Thalacker for his work in making Figure 1. Aldo Vecchia, Jr. of the USGS North Dakota Water Science Center in Bismarck, ND, provided the monthly lake water budget data for Devils Lake. Bill Schuh of the North Dakota State Water Commission provided the discharge data for the outlets on Devils Lake. Rhonda Fietzek-DeVries assisted with the running of the monthly water-balance model. 


\section{REFERENCES}

Barry R.G. \& Hall-McKim E.A. (2014) Essentials of the Earth's Climate System. Cambridge University Press, New York.

Bell G.D. \& Janowiak J.E. (1995) Atmospheric circulation associated with the Midwest floods of 1993. Bull. Am. Meteorol. Soc. 76, 681-695.

Benito G., Lang M., Barriendos M., et al. (2004) Use of systematic, paleoflood and historical data for the improvement of flood risk estimation. Review of scientific methods. Nat. Hazards 31, 623-643.

Bluemle J.P. \& Clayton L. (1984) Large-scale glacial thrusting and related processes in North Dakota. Boreas 13, 279-299.

Bluemle J.P., Sabel J.M. \& Karlén W. (1999) Rate and magnitude of past global climate changes. Environ. Geosci. 6, 63-75.

Chang H., Johnson G., Hinkley T. \& Jung I-W (2014) Spatial analysis of annual runoff ratios and their variability across the contiguous U.S. J. Hydrol. 511, 387-402.

Coe M.T. \& Foley J.A. (2001) Human and natural impacts on the water resources of the Lake Chad Basin. J. Geophys. Res. D 106 (D4), 3349-3356.

Daly C., Halbleib M., Smith J.I., et al. (2008) Physiographically sensitive mapping of climatological temperature and precipitation across the conterminous United States. Int. J. Climatol. 28, 2031-2064. 
Drummond M.A., Auch R.F., Karstensen K.A., Sayler K.L., Taylor J.L. \& Loveland T.R. (2012) Land change variability and human-environment dynamics in the United States Great Plains. Land Use Policy 29, 710-723.

Dumanski S., Pomeroy J.W. \& Westbrook C.J. (2015) Hydrological regime changes in a Canadian Prairie basin. Hydrol. Process. 29, 3893-3904.

Ehsanzadeh E., Spence C., van der Kamp G. \& McConkey B. (2012) On the behaviour of dynamic contributing areas and flood frequency curves in North American Prairie watersheds. J. Hydrol. 414-415, 2802-2813.

Feddema J.J. (2005) A revised Thornthwaite-type global climate classification. Phys. Geogr. 26, 442-466.

Grimm E.C., Donovan J.J. \& Brown K.J. (2011) A high-resolution record of climate variability and landscape response from Kettle Lake, northern Great Plains, North America. Quat. Sci. Rev. 30, 2626-2650.

Grundstein A. (2009) Evaluation of climate change over the continental United States using a moisture index. Clim. Chang. 93, 103-115.

Guppy L. \& Twigg J. (2013) Managing chronic crises and chronic hazard conditions. Environ. Hazards: Hum. Pol. Dimens. 12, 5-18.

Haskell B.J., Engstrom D.R. \& Fritz S.C. (1996) Late Quaternary paleohydrology in the North American Great Plains inferred from the geochemistry of endogenic carbonate and fossil ostracodes from Devils Lake, North Dakota, USA. Palaeogeogr. Palaeoclimatol. Palaeoecol. 124, 179-193. 
Hay L.E. \& McCabe G.J. (2002) Spatial variability in water-balance model performance in the conterminous United States. J. Am. Water Resour. Assoc. $38,847-860$.

Hirschboeck K. (1987) Catastrophic flooding and atmospheric circulation anomalies. In: Catastrophic Flooding. (eds L. Mayer \& D. Nash) pp. 23-56. Allen and Unwin.

Hoerling M., Eischeid J., Easterling D., Peterson T. \& Webb R. (2010) Understanding and explaining hydro-climate variations at Devils Lake. Climate Assessment. National Oceanic and Atmospheric Administration, Silver Spring, MD.

ILEC (2005) Managing Lakes and their Basins for Sustainable Use: A Report for Lake Basin Managers and Stakeholders. International Lake Environment Committee Foundation: Kusatsu, Japan.

van der Kamp G. \& Hayashi M. (2009) Groundwater-wetland ecosystem interaction in the semiarid glaciated plains of North America. Hydrogeol. J. 17, 203-214.

Kluver D. \& Leathers D. (2015) Regionalization of snowfall frequency and trends over the contiguous United States. Int. J. Climatol. 35, 4348-4358.

Knox J.C. (2000) Sensitivity of modern and Holocene floods to climate change. Quat. Sci. Rev. 19, 439-457. 
Kunkel K.E., Changnon S.A. \& Angel J.R. (1994) Climatic aspects of the 1993 Upper Mississippi River Basin flood. Bull. Am. Meteorol. Soc. 75, 811-822.

Laird K.R., Cumming B.F., Wunsam S., et al. (2003) Lake sediments record largescale shifts in moisture regimes across the northern prairies of North America during the past two millennia. PNAS 100, 2483-2488.

Larson D. (2012) Runaway Devils Lake. Am. Sci. 100, 46-53.

Leistriz F.L., Leitch J.A. \& Bangsund, D.A. (2002) Regional economic impacts of water management alternatives: The case of Devils Lake, North Dakota, USA. J. Environ. Manage. 66, 465-473.

Mason I.M., Guzkowska M.A.J., Rapley C.G. \& Street-Perrott F.A. (1994) The response of lake levels and areas to climatic change. Clim. Chang. 27, 161197.

McCabe Jr. G.J. \& Markstrom S.L. (2007) A monthly water-balance model driven by a graphical user interface. U.S. Geological Survey Open-File Report 20071088. United States Geological Survey, Boston.

McCabe Jr. G.J., Palecki M.A. \& Betancourt J.L. (2004) Pacific and Atlantic Ocean influences on multidecadal drought frequency in the United States. PNAS 101, 4136-4141.

McCabe G.J. \& Wolock D.M. (2002) Trends and temperature sensitivity of moisture conditions in the conterminous United States. Clim. Res. 20, 19-29.

McCabe G.J. \& Wolock D.M. (2011) Independent effects of temperature and 
precipitation on modeled runoff in the contermionous United States. Water Resour. Res. 47, W11522, doi:10.1029/2011WR010630.

McCabe Jr. G.J. \& Wolock D.M. (2014) Spatial and temporal patterns in conterminous United States streamflow characteristics. Geophys. Res. Lett. 41, 6889-6897, doi:10.1002/2014GL061980.

Merz B. et al. (2014) Floods and climate: emerging perspectives for flood risk assessment and management. Nat. Hazards Earth Syst. Sci. 14, 1921-1942.

Micklin P. (2007) The Aral Sea disaster. Annu. Rev. Earth Planet. Sci. 35, 47-72.

Mohammed I.N. \& Tarboton D.G. (2011) On the interaction between bathymetry and climate in the system dynamics and preferred levels of the Great Salt Lake. Water Resour. Res. 47, W0252, doi:10.1029/2010WR009561.

Morrisette P.M. (1988) The stability bias and adjustment to climatic variability: The case of the rising level of the Great Salt Lake. Appl. Geogr. 8, 171-189.

North Dakota State Water Commission (2014) Devils Lake Flood Facts [online]. Bismarck, ND. Available from: http://www.swc.nd.gov/4dlink9/4dcgi/GetContentPDF/PB206/Fact\%20Sheet.pdf [Accessed 29 September 2015].

Outcalt S.I., Hinkel K.M., Meyer E. \& Brazel A.J. (1997) Application of Hurst rescaling to geophysical serial data. Geogr. Anal. 29, 72-87.

Riebsame W.E. (1985) Climate hazards: Lessons from recent events in the United States. Disasters 9, 295-300. 
Risbey J.S. \& Entekhabi D. (1996) Observed Sacramento Basin streamflow response to precipitation and temperature changes and its relevance to climate impact studies. J. Hydrol. 184, 209-223.

Rosenberg N.J. (1986) Climate of the Great Plains region of the United States. Great Plains Q. 7, 22-32.

Ryan G.L. \& Wiche G.J. (1988) Hydrology of the chain of lakes tributary to Devils Lake and water-level simulations of Devils Lake, northeastern North Dakota. U.S. Geological Survey Water-Resources Investigations Report 88-4020. United States Geological Survey, Bismarck, ND.

Ryberg K.R., Lin W. \& Vecchia A.V. (2014) Impact of climate variability on runoff in the North-Central United States. J. Hydrol. Eng. 19, 148-158.

Saft M., Western A.W., Zhang L., Peel M.C. \& Potter N.J. (2015) The influence of multiyear drought on the annual rainfall-runoff relationship: An Australian perspective. Water Resour. Res. 51, 2444-2463, doi:10.1002/2014WR015348.

Sankarasubramanian A. \& Vogel R.M. (2003) Hydroclimatology of the continental United States. Geophys. Res. Lett. 30, 1363, doi:10.1029/2002GL015937.

Sethre P.R., Rundquist B.C. \& Todhunter P.E. (2005) Remote detection of prairie pothole ponds in the Devils Lake basin of North Dakota. GISci. Remote Sens. 42, 277-296.

Shapley M.D., Johnson W.C., Engstrom D.R. \& Osterkamp W.R. (2005) LateHolocene flooding and drought in the Northern Great Plains, USA, 
reconstructed from tree rings, lake sediments and ancient shorelines. The Holocene 15, 29-41.

Shaw D.A., van der Kamp G., Conly F.M., Pietroniro A. \& Mertz L. (2012) The fillspill hydrology of prairie wetland complexes during drought and deluge. Hydrol. Process. 26, 3147-3156.

Shaw D.A., Pietroniro A. \& Mertz L. (2013) Topographic analysis for the prairie pothole region of Western Canada. Hydrol. Process. 27, 3105-3114.

Shook K.R. \& Pomeroy J.W. (2011) Memory effects of depressional storage in Northern Prairie hydrology. Hydrol. Process. 25, 3890-3898.

Shook K., Pomeroy J. \& van der Kamp G. (2015) The transformation of frequency distributions of winter precipitation to spring streamflow probabilities in cold regions; case studies from the Canadian Prairies. J. Hydrol. 521, 395-409.

Small D., Islam S. \& Vogel R.M. (2006) Trends in precipitation and streamflow in the eastern U.S.: Paradox or perception? Geophys. Res. Lett. 33, L03403, doi:10.1029/2005GL024995.

Smith A.B. \& Katz R.W. (2013) US billion-dollar weather and climate disasters: Data sources, trends, accuracy and biases. Nat. Hazards 67, 387-410.

Spinioni J., Vogt J., Naumann G., Carrao H. \& Barbosa P. (2015) Towards identifying areas at climatological risk of desertification using the KöppenGeiger classification and FAO aridity index. Int. J. Climatol. 35, 2210-2222. 
Street F.A. (1980) The relative importance of climate and local hydrogeological factors in influencing lake-level fluctuations. Palaeoecol. Africa 12, 137-158.

Szesztay K. (1974) Water balance and water level fluctuations of lakes. Hydrol. Sci. Bull. 19, 73-84.

Todhunter P.E. \& Fietzek-DeVries R. (2016) Natural hydroclimatic forcing of historical lake volume fluctuations at Devils Lake, North Dakota (USA). Nat. Hazards 81, 1515-1532, doi:10.1007/s11069-015-2143-6.

Todhunter P.E. \& Rundquist B.C. (2004) Terminal lake flooding and wetland expansion in Nelson County, North Dakota. Phys. Geogr. 25, 68-85.

United States Geological Survey (2013) USGS 05056500 Devils Lake nr Devils Lake, ND [online]. Available from: http://nwis.waterdata.usgs.gov/nd/nwis/nwisman? [Accessed 15 November 2013].

United States Geological Survey (2014) Devils Lake and Stump Lake AreaCapacity Table [online]. Available from: http://nd.water.usgs.gov/devilslake/pdf/elevation-area-volume.pdf [Accessed 18 February 2014].

Vecchia A.V. (2002) Simulation of a proposed emergency outlet from Devils Lake, North Dakota. U.S. Geological Survey Water-Resources Investigations Report 02-4042. United States Geological Survey, Denver. 
Vecchia A.V. (2008) Climate simulation and flood risk analysis for 2008-40 for Devils Lake, North Dakota. U.S. Geological Survey Scientific Investigations Report 2008-5011. United States Geological Survey, Denver.

Waiser M.J. \& Robarts R.D. (2009) Saline inland waters. In: Encyclopedia of Inland Waters. (ed G.E. Likens) pp. 634-644. Academic Press.

Wiche G.J. \& Pusc S.W. (1994) Hydrology of Devils Lake Area, North Dakota. North Dakota State Water Commission Water Resources Investigation 22. North Dakota State Water Commission, Bismarck, ND.

Wiche G.J. \& Vecchia A.V. (1996) Lake-level frequency analysis for Devils Lake, North Dakota. U.S. Geological Survey Water-Supply Paper 2469. United States Geological Survey, Denver.

Williams W.D. (1996) What future for saline lakes? Environment 38, 13-20, 38-39.

Williams W.D. (1998) Management of Inland Saline Waters. Guidelines of Lake Management, No. 6, International Lake Environment Committee and United Nations Environment Programme, Kusatsu, Japan, and Nairobi, Kenya.

Williams W.D. (2000) Dryland lakes. Lakes Reserv. Res. Manage. 5, 207-212.

Williams W.D. (2002) Environmental threats to salt lakes and the likely status of inland saline ecosystems in 2025. Environ. Conserv. 29, 207-212.

Willmott C.J. \& Feddema J.J. (1992) A more rational climatic moisture index. Prof. Geogr. 44, 84-88.

Winter T.C. \& Rosenberry D.O. (1998) Hydrology of Prairie Pothole wetlands 
during drought and deluge: A 17-Year study of the Cottonwood Lake wetland complex in North Dakota in the perspective of longer term measured and proxy hydrological records. Clim. Chang. 40, 189-209.

Wolock D.M. \& McCabe G.J. (1999) Explaining spatial variability in mean annual runoff in the conterminous United States. Clim. Res. 11, 149-159.

Woodhouse C.A., Russell J.L. \& Cook E.R. (2009) Two modes of North American drought from instrumental and paleoclimatic data. J. Clim. 22, 4336-4347.

Zhang B., Schwartz F.W. \& Liu G. (2009) Systematics in the size structure of prairie pothole lakes through drought and deluge. Water Resour. Res. 45, W04421, doi:10.1029/2008WR006878.

Zheng H., Barta D. \& Zhang X. (2014) Lessons learned from adaptation response to Devils Lake flooding in North Dakota, USA. Reg. Environ. Chang. 14, 185194. 


\section{Figure captions}

Fig. 1. Location of Devils Lake Basin, North Dakota (USA). Lake extent is ca. 1999. Large, lake open water surfaces are shown in black; small, wetland open water surfaces are shown in gray. The Sheyenne River Basin is directly to the south; the lake level gaging station location is indicated with a star. Source: Sethre et al. (2005).

Fig. 2. Lake level ( $L$ L, $m)$ time series for Devils Lake; lake levels are included through 31 January 2014. Three phases of $L\llcorner$ are shown: lake rise to Stump Lake spillover elevation (1); Devils Lake discharging to Stump Lake until a common combined lake system lake level is reached (2); combined lake system rise to present (3).

Fig. 3. Normalized transformed time series plots of lake volume (black), annual water year precipitation (blue), and mean annual water year air temperature (red) for the period 1901-2011. The vertical dashed line marks the regime transition occurring in 1980 that separates hydroclimatic mode 1 from hydroclimatic mode 2 .

Fig. 4. Annual lake water budget totals for Devils Lake for water years 1951-2010.

Fig. 5. Runoff ratio (\%) for Devils Lake basin for water years 1951-2010. Individual years are shown with open diamonds; a 9-term binomial filter (solid curve) has been applied to the time series to clarify temporal variations. Horizontal red lines show the average value of RR for modes 1 and 2 . 